Ferdinand de Saussure

by Jonathan Culler

In the Penguin Modern Masters series, edited by Frank Kermode

Ferdinand de Saussure's role as the founder of modern linguistics alone would qualify him as a "modern master." Yet, as Jonathan Culler points out, Saussure has other claims to our attention. In this important new book, the author discusses Saussure's contribution to the fields of behavioral studies, anthropology, and literary criticism. His work, based on the notion of relativity, is the essence of modernist thought, and his treatment of language is central to new ways of thinking about man, especially about the connection between language and mind.

160 pages $\quad 0-14-004369-1$ 


\section{Semantics 1 \\ Semantics 2}

\section{JOHN LYONS}

This is a major new study of semantics. Volume 1 provides a general and comprehensive introduction, synthesising work on meaning and communication from many disciplines and setting semantics in the larger framework of semiotics. Little technical knowledge is presupposed, and all the relevant terms and concepts are carefully explained as they are used.

Volume 2, which can be read independently, deals with more specifically linguistic problems in semantics and contains substantial original material. There are in particular important theoretical chapters on Semantics and Grammar, Deixis, Mood and Illocutionary Force, and Modality.

1 Hard covers $\mathbf{£ 1 2 . 0 0}$ net Paperback E3.95 net

\section{Acoustic Phonetics}

\section{A Course of Basic Readings}

\section{Edited by D. B. FRY}

D. B. Fry has edited a basic course of readings on the acoustics of speech. The collection includes all the important classical papers in the field. It is carefully structured to present the student with a coherent picture of the relations between language units and the corresponding sound-waves and to explain the laws that govern these relations.

E8.75 net

\section{The Phoneme}

\section{Its Nature and its Use}

\section{The late DANIEL JONES}

The Phoneme, first published in 1950, is now not only a standard work on its subject but comprises Daniel Jones' major and final expression of his theoretical attitudes. This is a reissue of the third (1976) edition which includes the appendix on the history and meaning of the word 'phoneme'. It sets out in detail the author's conclusions about the nature and function of the phoneme, illustrating them from over 40 languages.

E6.50 net

\section{CAMBRIDGE UNIVERSITY PRESS}




\section{Talking to Children}

\section{Language Input and Acquisition}

\section{Edited by CATHERINE E. SNOW and CHARLES A. FERGUSON}

'Child language' is now established as a research area of real importance, a source of problems, data and insights for the converging interests of a growing range of linguists and social scientists. Some of the best work in the field is now brought together here.

$£ 8.00$ net

\section{CAMBRIDGE STUDIES IN LINGUISTICS 18}

\section{The Syntax of Welsh}

\section{A Transformational Study of the Passive \\ G. M. AWBERY}

The first full-length study of a Celtic language from the standpoint of modern linguistic theory. Dr Awbery particularly discusses a topic - the passive form of the verb-which has itself been a central interest in previous work of transformational grammar. She is thus able to test certain tenets of the transformational theory against data from a previously unconsidered language.

£8.50 net

\section{CAMBRIDGE STUDIES IN LINGUISTICS 19}

\section{A Grammar of Yidip?}

\section{R.M.W. DIXON}

Professor Dixon's book The Dyirbal Language of North Queensland (Cambridge 1972) is acknowledged to be a classic study, the first comprehensive account of an Australian Aboriginal language. His new study of Yidip is directly comparable in importance. Yidin, which is also a dying language, is Dyirbal's northerly neighbour, but the two languages have striking and fundamental differences in each area of grammar.

Forthcoming

About $£ 17.50$ net

\section{CAMBRIDCE STUDIES IN LINGUISTICS 20}

\section{Foundations of Theoretical Phonology}

\section{J. FOLEY}

The 'standard' theory of Chomsky and Halle has dominated phonology in recent years. It has, of course, been subject to modification and to criticism, but not of a really fundamental kind. Dr Foley does here offer a fundamental criticism and a genuine theoretical alternative.

About $\mathbf{E 6 . 5 0}$ net

\section{CAMBRIDGE UNIVERSITY PRESS}




\section{Oxford Books for Students}

\section{How to Do Things with Words}

J. L. Austin

J. L. Austin's 1955 William James Lectures, 'a choice work by one of the most acute and original minds that England has produced in our time' (The Times Literary Supplement), were first published in 1962, the printed version being based upon his very full lecture notes. For this second edition the editors have returned to the original notes, and their revision of text and appendix makes this a clearer, and, at the same time, more faithful record of Austin's words. Second edition $£ 1.50$

Oxford Paperbacks

New Orientations in the Teaching
of English

\section{Peter Strevens}

In this volume Mr. Strevens identifies and surveys these issues in applied linguistics and language-teaching methodology which currently constitute the major concerns of the field. Many of the papers which have appeared before in print have been substantially rewritten so that, together with the papers printed here for the first time, they make a volume which is a coherent and accessible account of those new orientations. It will be of importance to teachers in training and students of applied linguistics and education. Paper covers $£ 5$ Forthcoming

\section{The Edinburgh Course in Applied Linguistics}

Volume 4: Testing and Experimental Methods
Edited by J. P. B. Allen and Alan Davies

This volume is concerned with the role of testing and experimental methods in applied linguistics. This role is seen not only as an important extension of the theory and techniques discussed in Volumes 2 and 3 , but also as a separate and central element of applied linguistics. After an introductory chapter which discusses the relation between tests and experiments, chapters 2 and 3 consider tests, first from the general point of view and then from the practical one. Chapters 4, 5, and 6 then consider experiments ranging from the description of data to the analysis of results and the use inference theory. $£ 8.00$ Paper covers $£ 6$ Language and Language Learning 


\section{OXFORD edlucational}

Two new linguistics books from Oxford University Press

Halliday: System and Function in Language

Selected Papers Edited by Gunther Kress

M. A. K. Halliday's important contribution to theoretical and applied linguistics has long been recognised as fundamental but until now his writings have been dispersed over a very wide range of journals and other publications. This selection is doubly important in that it brings together for the first time some of the most important of these writings and also offers a coherent picture of the development of Halliday's theory. Several previously unpublished papers add to the value of the collection. Halliday's position as a teacher and a thinker is unique and the present selection has much to offer both the specialist and the general reader who wants to know more about this mainstream in British linguistics.

\section{The Edinburgh Course in Applied Linguistics}

Volume 4: Testing and Experimental Methods Edited by J. P. B. Allen and Alan Davies

This final volume of the course breaks new ground in bringing together papers on testing and experimental methods which will be of equal interest to applied linguists and language teachers involved in the actual process of test construction, and to people whose interest centres in statistics and testing procedures.

The other titles in the course are:

Volume 1: Readings for Applied Linguistics

Volume 2: Papers in Applied Linguistics

Volume 3: Techniques in Applied Linguistics

For details write to English Language Teaching Division, Oxford University Press, Walton Street, Oxford OX2 6DP 


\title{
Languages of the West Indies
}

\author{
Douglas Taylor
}

with an introduction by Sidney W. Mintz and Dell Hymes

Representing the culmination of more than forty years of linguistic and ethnographic research, Douglas Taylor's work presents the languages of the Caribbean in all their variegated richness. The author treats both the Amerindian languages of the Caribbean (Nepuyo, Shebayo, Yao, Taino, Arawak, and Island-Carib) and the so-called creole languages commonly associated with the enslaved Africans whose descendants make up the majority of the Caribbean population. In the series Johns Hopkins Studies in Atlantic History and Culture edited by Richard Price and Franklin W. Knight $\$ 16.00$

\section{Johns Hopkins}

The Johns Hopkins University Press Baltimore, Maryland 21218 


\section{Disorders of Fluency}

\section{And Their Effects on Communication}

\section{Peggy Dalton and W. J. Hardcastle}

\section{Studies in Language Disability and Remediation 3}

The authors address themselves to the problem of deciding what constitutes a pathological disfluency as distinct from 'normal' nonfluency. In the first part of the book, they bring together research findings from a wide variety of disciplines including speech therapy, phonetics, linguistics, language teaching, psychology and sociology in outlining some of the general factors contributing to an evaluation of fluency. In the second part they discuss those disorders usually considered to be specific fluency problems, namely stuttering and cluttering. The authors stress throughout that disruption of fluency is a disability affecting communication as a whole for both speaker and listener. Cloth £9.50 Paper $£ 4.50$

\section{Modern Phonology}

\section{Alan H. Sommerstein}

\section{Theoretical Linguistics 2}

A descriptive and critical survey of the main theoretical streams in twentieth-century phonology. Alan Sommerstein pays particular attention to the various forms of phonemic analysis, to Prague School phonology, and to the prosodic and stratificational theories. He gives a detailed account of generative phonology and the issues within it which have been the foci of investigation since the appearance of The Sound Pattern of English by Halle and Chomsky in I968. The book ends with a discussion of selected aspects of phonological change.

\section{Publication August Cloth $£ 12$ Paper $£ 5.95$}

If you would like further details of these and other Edward Arnold linguistic publications please contact Vicky Carne at the address below:

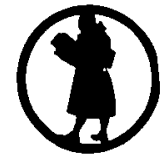

\section{Edward Arnold}

25 Hill Street, London WIX 8LL 


\section{CURRENT ISSUES IN LINGUISTIC THEORY}

\section{Edited by ROGER W. COLE}

This book is a state-of-the-art survey of a wide spectrum of subdisciplines within linguistics by some of the most prominent contributors to linguistic theory of our day. The areas covered include phonology, syntax, semantics, discourse theory, sociolinguistics, and historical linguistics. Taken together, the eight essays in this volume do more than exemplify a number of the most interesting approaches being taken in linguistics today: they point the directions in which the discipline and its most exciting sub-fields are likely to move in the coming decade.

Indiana 320 pp line drawings $\quad$ fl3.15

\section{THE STRUCTURE OF JACALTEC}

\section{COLETTE GRINEVALD CRAIG}

Written from the perspective of the transformation theory of grammar, The Structure of Jacaltec is a model study of the syntax of an unwritten language. It is the most thorough, modern syntactic exposition of a Mayan language ever to be published and is the first native American Indian grammar of such scope.

This book is an important contribution to general linguistic knowledge and to Mayan studies. It will be a research tool for linguists interested in language universals, a basic text for the study of descriptive linguistics and syntax, and a reference manual for all Mayan linguists.

Texas $440 \mathrm{pp}$ cloth $\mathfrak{£} 14.25$ paper $\mathbf{£} 7.50$

Please write for complete catalogues.

American University Publishers Group Ltd.

70 Great Russell Street, London WC1B 3BY Tel : 014050182 


\section{On the Other Hand}

\section{NEW PERSPECTIVES ON AMERICAN SIGN LANGUAGE}

Edited by LYNN A. FRIEDMAN

A Volume in the LANGUAGE, THOUGHT, AND CULTURE Series

CONTENTS: L. A. Friedman, Introduction. L. A. Friedman,

Formational Properties of American Sign Language. M. Mandel, Iconic Devices in American Sign Language. A. DeMatteo, Visual Imagery and Visual Analogues in American Sign Language.

$\checkmark$. Edge and L. Herrmann, Verbs and the Determination of Subject in American Sign Language. H. Thompson, The Lack of Subordination in American Sign Language. C. Cogen, On Three Aspects of Time Expression in American Sign Language. C. Baker, Regulators and Turn-Taking in American Sign Language Discourse. 1977, 260 pp., \$14.95/E10.65 ISBN: 0-12-267850-8

\section{Topics in Phonological Theory}

By MICHAEL KENSTOWICZ AND CHARLES KISSEBERTH

This book explores the questions of abstractness in underlying representations, providing up-to-date explications of this and other current issues in phonological theory: e.g., the role of syntax and lexicon in phonology, constraints on phonological representation, and the interaction between applications and ordering of phonological rules.

CONTENTS: The Problem of the Abstractness of Underlying Representations. The Nonphonetic Basis of Phonology. Constraints on Phonological Representations. Natural Rule Interactions. The Multiple Application Problem. The Role of Derivational History in Phonology.

1977, 242 pp., \$17.50/E12.40 ISBN: 0-12-405150-2

Send payment with order and save postage plus $50 \notin$ handling charge. Orders under $\$ 15.00$ must be accompanied by payment.

Prices are subject to change without notice.

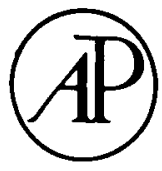

\section{ACADEMIC PRESS, INC.}

A Subsidiary of Harcourt Brace Jovanovich, Publishers

111 FIFTH AVENUE, NEW YORK, N.Y. 10003

24-28 OVAL ROAD, LONDON NW1 7DX

Please send me the following:

_copies, Friedman: On the Other Hand

_copies, Kenstowicz/Kisseberth: Topics in Phonological Theory

Check enclosed__ Bill me

NAME

ADDRESS

CITY/STATE/ZIP

New York residents please add sales tax.

Direct all orders to Mr. Paul Negri, Media Dept.

!ILIing $/ 9 / 77$ 


\section{New Volumes in the North-Holland Linguistic Series}

Volume 17

Transformational-Generative

Grammar

An Introductory Survey of Its Genesis and Development

by B. JACOBSEN

1977. XVi +562 pages. US $\$ 20.50 / D f 1.50 .00$

Volume 24

Soviet Studies in Language and Language Behavior

edited by J. PROCCHA

1976. 250 pages. Paperback.

US $\$ 30.95 /$ Dfl. 80.00

Volume 25

Lexical Structures in Syntax and

\section{Semantics}

1: Studies in Lexical Relations

II: Functions of the Lexicon in Formal

Descriptive Grammars

by J.S. GRUBER

1976. 388 paces. Paperback.

US $\$ 24.75 /$ Dfl. 65.00

Volume 26

\section{Asymmetry}

An Inquiry into the Linguistic Structure of Poetry

by M. SHAPIRO

1976. 245 pages. Paperback.

US $\$ 19.25 /$ Dfl. 50.00

Volume 27

\section{A Study of Metaphor}

On the Nature of Metaphorical Expressions, with Special Reference to their Reference by J.J.A. MOOIJ

1976. 206 pages. Paperback.

US $\$ 19.25 / \mathrm{Dfl} .50 .00$

\section{Volume 28}

The Expression of Future Time in Contemporary British English by H. Chr. WEKKER

1976. 186 pages. Paperback.

US $\$ 21.25 /$ Dfl. 55.00
Volume 29

A Theory of Word Order with Special Reference to Spanish by H. CONTRERAS

1976. 164 pages. Paperback. US \$17.50/Dfl. 45.00

Volume 30

New Approaches to Language Mechanisms

A Coliection of Psycholinguistic Studies edited by R. WALES and E. WALKER

1976. 304 pages. Paperback. US $\$ 18.75 /$ Dfl. 49.00

Volume 31

\section{Current Progress in}

Historical Linguistics

Proceedings of the Second International Conference on Historical Linguistics. Tucson Arizona, January 12-16, 1976.

edited by W.M. CHRISTIE

1976. 419 pages. US $\$ 39.00 / D f l, 100.00$

Volume 32

Studies in Modern Hebrew Syntax and Semantics

The Transformational-Generative Approach by P. COLE

1976. 298 pages. Paperback.

US $\$ 32.95 /$ DFI. 85.00

Volume 33

Phonological Structure and the History of English by JOHN M. ANDERSON and CHARLES JONES 1977. 198 pages. Paperback. US $\$ 19.50 / D$ fl. 52.50

\section{Volume 34}

\section{English Quantifier Systems} by R. M. HOGG

1977. viii +178 pages. US $\$ 22.50 /$ Dfl. 55.00 
S.K. Shaumyan

EXpressfrom Edinburgh

Applicational Grammar as a Semantic Theory of Natural Language was commissioned by Edinburgh University Press, and translated by Dr J.E. Miller. This new book by the distinguished Soviet linguist, now at Yale, proposes a semantic theory of language, based on the formal apparatus of applicational grammar. Shaumyan makes interesting use of the biological analogy of genotype and phenotype. $£^{8}$

J.C.Catford

Fundamental Problems in Phonetics is an original and comprehensive introduction to the nature and characteristics of the production by humans of vocal sounds. It deals with the aerodynamic and acoustic phases, and initiation, articulation, and phonation. $€ 8$

STANDARD TITLES

David Abercrombie

The Elements of General Phonetics

John Lyons \&

Roger Wales, editors Psycholinguistic Papers

Terry Winograd Understanding Natural Language

Kenneth H. Jackson Language and History in Early Britain
COMING THIS AUTUMN

R.K.S.Macaulay

Language, Social Class and Education. A study in the sociolinguistics of Glasgow. About $£ 4.50$

Edinburgh

University Press

22 George Square

Edinburgh

EH8 9LF 


\section{THE LINGUISTICS ASSOCIATION}

The Linguistics Association of Great Britain was founded in 1959 to promote the study of linguistics and to provide for its members both a forum for discussion and facilities for cooperation in furtherance of their interest in linguistics. The Association holds annual spring and autumn meetings, at which original papers are presented in plenary sessions and in section meetings devoted to special interests.

Persons interested in linguistics are eligible for election as members, subject to the approval of the Committee. Subscribing members may receive the Journal of Linguistics at the special rate of $£ 7.00$ per annum. Application forms for membership may be obtained from the membership Secretary, Dr. R. Hogg, Department of English Language and Medieval Literature, University of Lancaster, Lancaster LA ${ }_{4} \mathrm{YT}$.

\section{COMMITTEE MEMBERS}

Chairman: Prof. E. Henderson, Dept. of Phonetics \& Linguistics, School of Oriental \& African Studies, Malet Street, London WCIE $7 \mathrm{HP}$.

Hon. Secretary: Mr. A. R. Warner, Dept. of Language, University of York, Heslington, York YOI 5 DD.

Membership Secretary: Dr. R. Hogg, Dept. of English Literature \& Medieval Literature, University of Lancaster, Bailrigg, Lancaster LAI 4 YT.

Meetings Secretary: Dr. P. Werth, Dept. of Linguistics, University of Hull, Hull HU6 7 RX.

Treasurer: Ms. C. Cullen, Dept. of Language, University of York, York YOr 5 DD.

Assistant Secretary: Dr. G. Gazdar, School of Social Sciences, University of Sussex, Falmer, Brighton BNI $9 \mathrm{QN}$.

Assistant Meetings Secretary: Dr. G. Pullum, Linguistics Section, University College London, Gower Street, London WC I E 6BT.

\section{BRITISH NATIONAL COMMITTEE FOR LINGUISTICS}

A British National Committee for Linguistics has been set up under the aegis of the British Academy, in the first instance for a period of three years. It is intended that it shall keep under review relations with international bodies in the field of linguistics, provide a channel of communication between such bodies and British linguists, and hold consultations on matters of common interest and concern. The committee is composed of three representatives from the British Academy, and two each from the LAGB, the Philological Society and the British Association for Applied Linguistics. The chairman is Professor John Lyons of Sussex University, and the LAGB representatives are Professor R. B. Le Page of York University and Mr. C. Butler of Nottingham University.

\section{SPRING MEETING I977}

The Spring Meeting of the Association was held at the West Midlands College, Walsall on 29-31 March 1977. The following papers were presented to the Association: R. B. Le Page (York): De-creolization and re-creolization in St. Lucia

M. Deuchar (Stanford): Sign language diglossia in a British deaf community

E. Braroe (Umeâ): On limiting theses in an adequate

J. Coates \& G. Leech (Lancaster): A corpus-based comparison of modal auxiliaries in British and American English: a progress report

D. Reibel (Túbingen): The syntax and pragmatics of the imperative in English

D. Lightfoot (McGill): The changing syntax of English quantifiers

R. Hogg (Lancaster): The Duke of York gambit: a variation
B. Comrie (Cambridge): Ergativity and morphology

D. C. Derbyshire (University College London): First report on an O-V-S language

B. Butterworth (Cambridge) \& G. Gazdar (Sussex): Quantifier contraction

G. G. Gorbett (Surrey): The numeral squish

K. Allan (Nairobi): Some characteristics of English numeral classifiers

J. K. Chambers (Toronto): Where's the isogloss ?

E. Klein (Bedford College London): A nondiscrete

treatment of the referential/non-referential distinction J. Hurford (Lancaster): Garbage

P. Werth (Hull): Focus-pocus

R. Hetzron (Santa Barbara): Emphasis vs. contrast

Syntax workshop-Grammatical relations and the status of complement clauses

J. Payne (Birmingham): Seem complements

A. Radford (Oxford): On raising in relational grammar 


\section{JOURNAL OF LINGUISTICS, VOL. 13, No. 2 \\ SEPTEMBER 1977}

\section{CONTENTS}

\section{ARTICLES}

D. A. Cruse: The pragmatics of lexical specificity

Richard M. Hogg: Old English $r$-metathesis and generative phonology

AnITA MirTwoch: How to refer to one's own words: speech-act modifying adverbials and the performative analysis

DAvid LighrFoot: Syntactic change and the autonomy thesis

Shmuel BolozkY: Fast speech as a function of tempo in natural generative phonology

JAN TERJE FAARLUND: Embedded clause reduction and Scandinavian gender agreement

IRENE P. WARBURTON: Modern Greek clitic pronouns and the 'surface structure constraints' hypothesis

NOTES AND DISCUSSIONS

TERRY J. KLOKEID: Some irrelevant observations concerning rule interaction

\section{REVIBWS}

Nus B. Thelin: Notes on general and Russian morphology; Nils B. THELIN: Towards a theory of verb stem formation and conjugation in modern Russian. With an excursus on so-called $e-0$ alterations and mobile vorvels (Sussex)

DEREK BICKERTON: Dynamics of a Creole system (Sankoff)

ANDRE MARTINET \& HENRIETTE WALTER: Dictionnaire de la prononciation francaise dans son usage réel; HeNRIETTE WALTRR: La dynamique des phonèmes dans le lexique francais contemporain (Vincent)

KARL-GUNNAR LINDKVIST: The local sense of the prepositions OVER, ABOVE, and ACross studied in present-day English (Bennett)

Barbara H. Partee (ed.): Montague grammar (Cohen)

JosePH E. GrImes: The thread of discourse (Dressler)

RODNEY Huddeston: An introduction to English transformational syntax (Lehrer)

PETER LADEFOGED: $A$ course in phonetics (Wells)

ROGER T. BELL: Sociolinguistics-goals, approaches and problems (Hudson)

LowELL BOUMA: The semantics of the modal auxiliaries in contemporary German (Salmon)

ROGER LASS: English phonology and phonological theory: synchronic and diachronic studies (Hogg)

Samuel E. Martin: $A$ reference grammar of fapanese (Shibatani)

\section{SHORTER NOTICES}

SAUL LeVIN: The Indo-European and Semitic languages (Hetzron)

EMMA VoRLAT: The development of English grammatical theory I586-I737 with special reference to the theory of parts of speech (Salmon)

MERRITT RUHLEN: A guide to the languages of the voorld (Hamp)

H. CHR. WEKKER: The expression of future time in contemporary British English: an investigation into the syntax and semantics of five verbal constructions expressing futurity (Huddleston)

PUBLICATIONS RECEIVED

(C) Cambridge University Press, 1977 